\title{
DIAGNOSTIC ACCURACY OF HIGH-FREQUENCY DISTORTION- PRODUCT OTOACOUSTIC EMISSION SCREENING OF SCHOOLCHILDREN WITH DOWN SYNDROME
}

\author{
Carlie Driscoll, Joseph Kei, Kate Hearn, Trina Walsh, Sarah Swann
}

Hearing Research Unit for Children, School of Health and Rehabilitation Sciences, The University of Queensland, Queensland, Australia

Corresponding author: Carlie Driscoll, School of Health and Rehabilitation Sciences, The University of Queensland, St Lucia, Queensland, 4072, Australia, Ph: +61 73365 3095, Fax: +61 73365 1877, e-mail: carlie.driscoll@uq.edu.au

\begin{abstract}
Background: It has been suggested that children with Down syndrome (DS) may display high frequency hearing loss much earlier than those in the general population. The purpose of this study was to investigate the diagnostic accuracy of high-frequency distortion-product otoacoustic emissions (HFDPOAEs) as a screening technique for schoolchildren with DS.

Materials and methods: Exactly 25 children with DS ( 15 males, 10 females, mean age $=9.7$ years, $S D=2.6$ ) were sampled from six special education schools. HFDPOAE results were compared to the reference test results - high-frequency pure tone audiometry (HFPTA) at 8 and $10 \mathrm{kHz}$.

Results: Test performance was found to reach adequate levels $(\geq 0.7)$ of accuracy for HFDPOAE SNR at $8 \mathrm{kHz}$ and $10 \mathrm{kHz}$. The hit rate at $8 \mathrm{kHz}$ was average, but moderately high at $10 \mathrm{kHz}$. True negative rates and positive posterior probabilities for the HFDPOAE test were high, and false alarm rates were acceptably low. However, the false negative rate was average at $8 \mathrm{kHz}$ and negative posterior probabilities were moderately high at both frequencies. Efficiency index values were high indicating that a large proportion of HFDPOAE results were correct when compared with HFPTA results.
\end{abstract}

Conclusions: Initial findings support the potential future use of HFDPOAE for screening children with DS for high-frequency hearing loss.

Keywords: accuracy $\bullet$ Down syndrome $\bullet$ high-frequency distortion-product otoacoustic emissions $\bullet$ high-frequency pure-tone audiometry $\bullet$ schoolchildren $\bullet$ screening

\section{LA PRECISIÓN DEL DIAGNÓSTICO CON APLICACIÓN DE LA EMISIÓN} OTOACÚSTICA DE ALTAS FRECUENCIAS DE LOS PRODUCTOS DE DISTORSIONES NO LINEALES EN LAS PRUEBAS DE CRIBADO EN NIÑOS EN LA EDAD ESCOLAR CON SÍNDROME DE DOWN

\section{Resumen}

Introducción: Se sugiere que los niños con síndrome de Down (SD) pueden padecer la pérdida auditiva en el rango de frecuencias altas mucho antes que otros niños. El objetivo de este estudio ha sido el de comprobar la precisión del diagnóstico con aplicación de la emisión otoacústica de altas frecuencias de distorsiones no lineales (HFDPOAE) como técnica de las pruebas de cribado en niños con el síndrome de Down.

Materiales y métodos: Han sido examinados 25 niños con el síndrome de Down (15 niños varones, 10 niñas, media de la edad =9,7 años, DS=2,6) de 6 escuelas especiales. Los resultados de HFDPOAE han sido comparados con los resultados de prueba de referencia: audiometría tonal de altas frecuencias (HFTPA) para 8000 y $10000 \mathrm{~Hz}$.

Resultados: Durante el estudio se han conseguido unos niveles satisfactorios $(\geq 0,7)$ de la precisión HFDPOAE SNR para las frecuencias de 8000 y $10000 \mathrm{~Hz}$. La sensibilidad para $8000 \mathrm{~Hz}$ era media, y para los 10000-moderamente alta. Los indicadores de probabilidad realmente negativos y positivos a posteriori de las pruebas HFDPOAE eran altas, la incidencia de alarmas falsas era respectivamente bajas. Sin embargo, la incidencia de la presencia de los resultados falsamente negativos para los 8000 $\mathrm{HZ}$ era media, y las probabilidades negativas a posteriori eran moderamente altas para ambas frecuencias. Los valores de eficiencia eran altos, lo que indica que una gran parte de los resultados de HFDPOAE ha sido correcta en comparación con los resultados de HFPTA. 
Conclusiones: Los resultados preliminares parecen indicar que la prueba HPDPOAE puede ser aplicada como una prueba de cribado en las pérdidas auditivas de altas frecuencias en los niños con el síndrome de Down.

Palabras clave: precisión • síndrome de Down • emisión otoacústica de altas frecuencias de los productos de distorsiones no lineales (HFDPOAE) • audiometría tonal de altas frecuencias (HFPTA) • niños en la edad escolar • pruebas de cribado

\section{ТОЧНОСТЬ ДИАГНОСТИКИ С ИСПОЛЬЗОВАНИЕМ ВЫСОКОЧАСТОТНОЙ ОТОАКУСТИЧЕСКОЙ ЭМИССИИ ПРОДУКТОВ НЕЛИНЕЙНОЙ ДЕФОРМАЦИИ В ПРОВЕРОЧНЫХ ИССЛЕДОВАНИЯХ У ДЕТЕЙ ШКОЛЬНОГО ВОЗРАСТА С СИНДРОМОМ ДАУНА}

\section{Изложение}

Введение: Предполагается, что дети с синдромом Дауна (DS) могут проявлять тугоухость в области высоких частот значительно ранее других детей. Цель исследования - проверка точности диагностики с использованием высокочастотной отоакустической эмиссии продуктов нелинейной деформации (HFDPOAE) как техники проверочных исследований у детей с синдромом Дауна.

Материалы и методы: Были исследованы 25 детей с DS (15 мальчиков, 10 девочек, средний возраст =9,7 лет, $\mathrm{DS}=2,6)$ из шести специальных школ. Результатыz HFDPOAE были сравнены с результатами референционного теста - тональной аудиометрии высоких частот (НFРТА) для 8000 и 10000 Гц.

Результаты: Во время исследования достигнуты удовлетворительные уровни $(\geq 0,7)$ точности HFDPOAE SNR для частот 8000 и 10000 Гц. Чувствительность для 8000 Гц была средней, а для 1000 - умеренно высокой. Подлинные отрицательные показатели и положительные правдоподобия апостериори были высокими, частоты фальшивых сигналов тревоги были соответственно низкими. Однако, частота появления фальшиво- отрицательных результатов для 8000Гц была средней, а отрицательные правдоподобия апостериори были умеренно высокими для обеих частот. Значения показателя эффективности были высокими. Это показывает, что значительная часть результатов HFDPOAE была правильной в сравнении с результатами НFРТА.

Итоги: Предварительные результаты показывают, что HPDPOAЕ могут применяться как проверочный тест в области тугоухости у детей с синдромом Дауна.

Ключевые слова: точность • синдром Дауна • высокочастотная отоакустическая эмиссия продуктов нелинейной деформации (HFDPOAE) • тональная аудиометрия частот (HFPTA) • дети школьного возраста • проверочные исследования

\section{DOKŁADNOŚĆ DIAGNOSTYKI Z ZASTOSOWANIEM WYSOKOCZĘSTOTLIWOŚCIOWEJ EMISJI OTOAKUSTYCZNEJ PRODUKTÓW ZNIEKSZTAŁCEŃ NIELINIOWYCH W BADANIACH PRZESIEWOWYCH U DZIECI W WIEKU SZKOLNYM Z ZESPOŁEM DOWNA}

\section{Streszczenie}

Wprowadzenie: Sugeruje się, że dzieci z zespołem Downa (DS) mogą wykazywać niedosłuch w zakresie wysokich częstotliwości znacznie wcześniej niż inne dzieci. Celem badania było sprawdzenie dokładności diagnostyki z zastosowaniem wysokoczęstotliwościowej emisji otoakustycznej produktów zniekształceń nieliniowych (HFDPOAE) jako techniki badań przesiewowych u dzieci z zespołem Downa.

Materiały i metody: Zbadano 25 dzieci z DS (15 chłopców, 10 dziewczynek, średnia wieku =9,7 lat, DS=2,6) z sześciu szkół specjalnych. Wyniki HFDPOAE zostały porównane z wynikami testu referencyjnego - audiometrii tonalnej wysokich częstotliwości (HFPTA) dla 8000 i $10000 \mathrm{~Hz}$.

Wyniki: Podczas badania osiągnięto zadowalające poziomy $(\geq 0,7)$ dokładności HFDPOAE SNR dla częstotliwości 8000 i $10000 \mathrm{~Hz}$. Czułość dla $8000 \mathrm{~Hz}$ była średni, a dla 10000 - umiarkowanie wysoka. Wskaźniki prawdziwie ujemne i dodatnie prawdopodobieństwa a posteriori badań HFDPOAE były wysokie, częstości fałszywych alarmów były odpowiednio niskie. Jednakże, częstość wystąpienia wyników fałszywie negatywnych dla $8000 \mathrm{~Hz}$ była średnia, a negatywne prawdopodobieństwa 
a posteriori były umiarkowanie wysokie dla obu częstotliwości. Wartości wskaźnika efektywności były wysokie, co wskazuje, że duża część wyników HFDPOAE była prawidłowe w porównaniu z wynikami HFPTA.

Wnioski: Wstępne wyniki wskazują że HPDPOAE mogą mieć zastosowanie jako test przesiewowy w zakresie niedosłuchu w wysokich częstotliwościach u dzieci z zespołem Downa.

Słowa kluczowe: dokładność • zespół Downa • wysokoczęstotliwościowa emisja otoakustyczna produktów zniekształceń nieliniowych (HFDPOAE) • audiometria tonalna wysokich częstotliwości (HFPTA) • dzieci w wieku szkolnym • badania przesiewowe

\section{Background}

Down syndrome (DS) in children has long been associated with a high prevalence of both congenital and acquired hearing loss [1-3]. An extensive range of anomalies have been noted across the auditory system in DS populations - e.g., reduced pinna size, stenotic ear canals, Eustachian tube dysfunction and chronic ear infections, as well as deformities in the inner ear - resulting in varying degrees of conductive and sensorineural hearing loss [2,4-7]. Earlyonset presbycusis may present an additional concern $[4,8]$. Presbycusis affects the high frequencies first and, in the general population, most commonly becomes evident in the $7^{\text {th }}$ decade of life, brought on by degeneration of the cochlea with age [9]. However, in children with Down syndrome it has been reported that, by the $2^{\text {nd }}$ decade of life, presbycusis may already be affecting hearing thresholds within the conventional frequency range [8]. This phenomenon is central to the present study.

Although children with DS are clearly at high risk of hearing loss, the exact hearing status of many children with DS is often overlooked or unknown $[4,10,11]$. Reliable screening is necessary for this group in order to minimise the compounding negative effects of hearing loss on other developmental delays $[1,12]$. Children with Down syndrome commonly experience other medical concerns or contraindications at birth that prevent them from benefiting from universal newborn hearing screening [13]. Later, standard school screening techniques present problems in testing children with special needs due to difficulties, while performing behavioral tests, with attention, memory, cognition, and delays in psychomotor function $[4,14]$. Whereas tympanometry has proven successful in detecting conductive problems in schoolchildren with DS [13], isolating sensorineural hearing loss, such as presbycusis, is less straightforward. With reliable behavioral results unattainable in up to $50 \%$ of young children with DS [8], various objective tests have been promoted as alternatives.

Auditory brainstem response (ABR) testing has had success in assessing DS groups for sensorineural hearing loss [15], but is unable to easily measure frequency-specific thresholds. Furthermore, structural differences typical of DS in the auditory nervous system create waveform anomalies which prevent comparisons with normative data $[6,15]$. The need for sedation or anesthesia during ABR can also be expensive, inconvenient, and may introduce other health concerns [16]. These factors make ABR a potentially complicated and inefficient method for assessing the hearing function of individuals with DS.
Several large studies have found transient-evoked otoacoustic emission (TEOAE) testing, combined with tympanometry, to be feasible and time-efficient for special school screenings [10,14]. However, middle ear pathologies significantly reduce TEOAE amplitudes, preventing accurate cochlear assessment [17]. In addition, the frequency capabilities of TEOAE systems generally do not exceed 5 $\mathrm{kHz}$. As a result of limitations in available testing devices, the high-frequency audition of children with DS has not been explored in detail to date. Considering the risk of presbycusis for children with DS, and the importance of high-frequency hearing for speech discrimination and localisation in noise [18], a screening device which extends above $5 \mathrm{kHz}$ could be highly beneficial.

High-frequency distortion-product otoacoustic emissions (HFDPOAEs) can objectively assess the auditory system, up to the level of the cochlea, at frequencies of up to $16 \mathrm{kHz}$ [18]. The physiological mechanisms behind HFDPOAEs mirror those of traditional distortion-product otoacoustic emissions (DPOAEs) [19]. When two mathematically related primary tones $\left(f_{1}\right.$ and $\left.f_{2}\right)$ are presented to the cochlea, cochlear amplifier mechanisms generate tiny recordable emissions. This process depends on intact outer hair cell function around the geometric mean of the primary frequencies [20]. It has been well established that conventional-range DPOAE testing is a relatively accurate way of identifying frequency-specific sensorineural loss [20].

Dreisbach and Siegel [19] suggested that HFDPOAEs may be suitable for investigating the functionality of the basal region of the cochlea and, hence, for assessment of ultrahigh-frequency hearing up to $16 \mathrm{kHz}$. Although relatively little research exists in this area, particularly as applied to pediatric populations, several potentially beneficial applications are evident. These include monitoring conditions that affect the ultra-high-frequencies first, such as early-stage presbycusis and sensorineural loss due to ototoxic therapy [21-23]. The existing literature does support the plausibility of using HFDPOAE measurements during hearing screenings. Investigations of the relationship between DPOAEs and pure tone audiometry (PTA) in adults [20] and children [24] have found that changes in DPOAE amplitudes were sensitive and specific to the loss exemplified by the behavioral thresholds. Gorga et al. [25] found that DPOAEs were almost $100 \%$ accurate in identifying a hearing-impaired ear for losses over $40 \mathrm{~dB}$ HL. These findings are indicative of an association between DPOAEs and hearing thresholds, implying that DPOAEs might be able to provide an overview of hearing sensitivity in situations where testing behavioral thresholds is not possible. It remains to be seen whether the association is also evident between HFDPOAEs and its corresponding 
reference test, high-frequency pure tone audiometry (HFPTA). In collecting a normative data set for HFPTA in children, Beahan et al. [26] established the basis for meaningful interpretation of hearing loss identified using HFPTA. This approach can allow a comparison between HFPTA and HFDPOAEs to be made, and perhaps to determine whether HFDPOAEs are accurate in identifying hearing loss in children with DS.

Although an exhaustive body of literature on HFDPOAEs in children is not yet available, some important limitations related to HFDPOAEs have been defined. Firstly, the variability observed across and within subjects is a known issue. Standing waves in the ear canal affect stimulus-level calibrations at frequencies greater than $2-3 \mathrm{kHz}$ [27]. Calibration of sound pressure levels at the eardrum is thought to minimise these effects [19], as is a deliberate variation of probe insertion depth [28]. However, Dreisbach et al. [23] still attribute the substantial variability in HFDPOAEs above $10 \mathrm{kHz}$ to standing-wave effects, and this issue is compounded by probe placement discrepancies [27]. Stenotic ear canals, which are typical of children with DS [5], could potentially worsen such effects. While variability remains an important issue, it bodes well that HFDPOAE results appear fairly repeatable for the key measures of amplitude and group delay [23]. Furthermore, a recent engineering study by Hecker et al. [29] into alternative algorithms for measuring HFDPOAE stimulus levels suggests possible improvements in future instrumental accuracy.

Another significant limitation may be the effect of middle ear status on DPOAE amplitude [30]. Middle ear effusion, often related to Eustachian tube dysfunction, is common in children with DS [5]. Proactive medical management has been shown to often resolve conductive problems in this group [2]. The minimisation of reversible conductive problems is likely to be important to the success of using serial HFDPOAEs to monitor high-frequency loss. Kei et al. [31] has examined the effect of middle ear dysfunction on HFDPOAEs. Findings showed that while HFDPOAE amplitudes were lower for all frequencies in the presence of middle ear dysfunction, the results were less impacted in the extended high frequencies than in the conventional frequency range. Although only utilising a small sample size, this research is in line with other studies showing that lower frequency DPOAE responses are more affected by middle ear disease than higher frequencies [32].

It is clearly important to establish an accurate screening technique for children with DS, who are traditionally difficult to test and known to be at risk of early presbycusis. The provision of appropriate interventions, including (soundfield) amplification, assistive listening devices, audiological monitoring, and environmental modifications have been widely shown to improve development and overall quality of life in children with DS and hearing loss $[1,33,34]$. This highlights the importance of early detection of high-frequency hearing loss in this group, a topic on which there is currently a substantial gap in the literature. HFDPOAEs present the possibility of an objective, non-invasive, and efficient screening tool suitable for this purpose.

The current study aims to establish the diagnostic accuracy of HFDPOAEs through comparison with the current reference standard of HFPTA in schoolchildren with DS. This focal group has been chosen due to their predisposition to early-onset presbycusis, along with the need to establish an effective screening method for use in this population. It is suggested that the test performance of HFDPOAEs, specifically the overall accuracy in differentiating between children with and without high frequency hearing loss, will prove acceptable $(\geq 0.7)$.

\section{Materials and methods}

\section{Participants}

A total of 25 children with DS participated in the study (15 males, 10 females), aged between 5.6 and 13.7 years ( mean $=9.7, \mathrm{SD}=2.6$, median $=9.4$ ). Subjects were sampled from six special education state schools in and around Brisbane, Australia, where teachers had been asked to distribute consent forms, information forms, and questionnaires to all enrolled students with DS. Participation was voluntary, and written consent was obtained from caregivers prior to data collection. A brief caregiver questionnaire was collected to obtain information regarding previous hearing tests, caregiver hearing concerns, history of familial hearing loss, middle ear infections, ear or head surgery, and noise exposure. Children with cleft palate or a history of maxillofacial surgery were excluded from this study, as were children with discharging ears or atresia in both ears. Ethical clearance was obtained from both the University of Queensland Behavioral and Social Sciences Ethical Review Committee and Education Queensland.

\section{Procedure}

Testing was conducted by an experienced pediatric audiologist assisted by final-year Master of Audiology students. Each subject was tested individually during school hours in the quietest available room at each school. The ambient noise levels in the test rooms ranged from 30 to $35 \mathrm{~dB}$ A, as measured by a Bruel and Kjaer 2250 sound level meter with frequency analysis software BZ-7223. Subjects were tested in a seated position. Where feasible, teacher aides or caregivers were present during the testing to provide support.

Otoscopic examination was performed first in order to identify possible medical contraindications, and to ensure that issues such as wax occlusion or collapsing ear canals would not affect subsequent results. Tympanometry testing, using a Madsen Otoflex tympanometer, was then conducted to investigate middle ear function. This equipment was calibrated at the commencement of each test day, using a built-in 2 cc cavity. A $226 \mathrm{~Hz}$ probe tone was delivered into the canal, with pressure varying at $200 \mathrm{daPa} / \mathrm{s}$ from +200 to $-400 \mathrm{daPa}$, to produce a tympanogram of admittance (mmho) against ear canal pressure (daPa). For each ear, the ear canal volume (ECV), tympanometric peak pressure (TPP), static compliance (SC), and tympanometric width (TW) were recorded. The Jerger [35] tympanogram type was also recorded. Pass results were achieved with Type $\mathrm{A}$ or Type $\mathrm{C}_{1}$ tympanograms (Type A: $\mathrm{SC}=0.2$ to $1.6 \mathrm{~mL}, \mathrm{TPP}=+50$ to $-100 \mathrm{daPa}$; Type $\mathrm{C}_{1}$ : $\mathrm{SC}=0.2$ to $1.6 \mathrm{~mL}, \mathrm{TPP}=-101$ to $-200 \mathrm{daPa})$. Type $\mathrm{B}$ or $\mathrm{C}_{2}$ tympanograms were classified as fail results. Children with fail results were referred to their family doctor for medical advice. 
Table 1. HFPTA pass limits for $10 \mathrm{kHz}$ (dB SPL), based on mean and SD values (dB SPL) of thresholds from normative data by Beahan et al. (2009)

\begin{tabular}{ccccccc}
\hline \multirow{2}{*}{ Frequency $[\mathrm{kHz}]$} & \multicolumn{2}{c}{ 4-6 years } & \multicolumn{2}{c}{ 7-9 years } & \multicolumn{2}{c}{ 10-13 years } \\
\cline { 2 - 7 } & Mean (SD) & Pass limit & Mean (SD) & Pass limit & Mean (SD) & Pass limit \\
\hline \multirow{2}{*}{10} & $28.7(10.6)$ & 49.9 & $22.3(7.4)$ & 37.1 & $22(8.6)$ & 39.2 \\
\hline
\end{tabular}

Following tympanometry, HFPTA and HFDPOAE tests were then conducted, with a break of 5 to 10 minutes permitted between these tests to minimise the effects of fatigue. HFPTA and HFDPOAE tests were completed in alternating order per participant. For each participant, a different starting ear was used for each test.

An Interacoustics AC40 clinical audiometer, calibrated annually by an experienced technician, was used to administer HFPTA testing. Calibration ensured that the output of the audiometer met requirements of the Australian Standard (AS IEC 60645.1-2002) [36] in terms of frequency accuracy, sound pressure levels $( \pm 5 \mathrm{~dB})$, harmonic distortion, on/off ratio, and rise/fall times. Reference sound pressure levels used for calibration were in accordance with Australian Standards (AS ISO 389.1-2007 for 0.125-8 kHz and AS ISO 389.5-2003 for above $8 \mathrm{kHz}$ ) [37,38]. Supra-aural TDH-39 headphones were used to obtain thresholds in the conventional frequency range $(1,2$, and $4 \mathrm{kHz})$. Koss $\mathrm{R} / 80$ headphones, which have been proven reliable in obtaining ultra-high-frequency thresholds [39], were used to obtain thresholds at 8 and $10 \mathrm{kHz}$.

Given the range of ages included, and the psychomotor and attention delays associated with DS [4], the audiologist made a case-by-case decision on whether to conduct conventional audiometry or play audiometry. If present, caregivers or teacher aides provided information regarding the child's overall development, motor skills, and ability to attend and respond, as recommended by Kile [4]. Testing commenced only when the audiologist was satisfied that the child was responding reliably.

Hearing at 1,2, and $4 \mathrm{kHz}$ was screened at an intensity of $20 \mathrm{~dB}$ HL. Failure to respond to two of three consecutive presentations at $20 \mathrm{~dB}$ HL was considered a fail result, following which the child's threshold was obtained using the modified Hughson-Westlake procedure [40]. For the high frequencies ( 8 and $10 \mathrm{kHz}$ ), thresholds were obtained using the modified Hughson-Westlake procedure [40]. Using this procedure, good test-retest reliability has been demonstrated for HFPTA, with Beahan et al.s [41] study of 125 normally hearing children demonstrating no significant differences in various age groups' mean thresholds between test and retest conditions.

At $8 \mathrm{kHz}$, thresholds equal to or better than $20 \mathrm{~dB}$ HL were considered a pass result. At $10 \mathrm{kHz}$, age-specific pass/fail criteria were established using normative data from Beahan et al.s [26] study of 129 normally-hearing children (see Table 1), in view of the known age effect on HFPTA thresholds. In the present study, thresholds equal to or less than the mean $+2 \mathrm{SD}$ were awarded pass results. A correction factor of +17 was used to convert thresholds from dB HL to dB SPL, as specified by Beahan et al. [26].
DPOAEs were recorded using a DP2000 system (Starkey Laboratories, Inc.) connected to a laptop computer. Following probe insertion, the system was calibrated in order to account for the acoustic properties of the individual ear canal. Calibration chirps were delivered into the ear via two channels, with the resultant frequency responses plotted on a graph of sound pressure level against frequency. Overlapping or almost overlapping frequency responses across $1-10 \mathrm{kHz}$ indicated a good probe seal [22,31]. If this was not achieved, the probe tip was reinserted until calibration indicated a good seal.

Using the extended evaluation $(0.5-8 \mathrm{kHz})$ mode and the high frequency $(8.7-16 \mathrm{kHz})$ mode of the DP2000 system, DPOAEs at $2 f_{1}-f_{2}$ were measured. The stimulus consisted of a series of simultaneous pure-tone pairs at frequencies $f_{1}$ and $f_{2}$, with a frequency ratio $\left(f_{2} / f_{1}\right)$ of 1.2 . This ratio has been shown to yield maximum DPOAE amplitude in humans [20]. Moderate intensity levels of 65 and $55 \mathrm{~dB}$ SPL were used for $f_{1}$ and $f_{2}$ respectively, to achieve clinically accurate results with minimal stimulus artefacts $[42,43]$.

A DP-gram (a plot of distortion-product amplitude and noise floor against $f_{2}$ frequency) was provided by the system. Measurement parameters of distortion-product amplitude (AMP), noise floor (NF), and distortion-product signal-to-noise ratio (SNR, calculated as AMP minus NF) were collected at each $f_{2}$ frequency $(984,1500,2016,3000$, $3984,6000,8016$, and $9984 \mathrm{~Hz}$ ). This study focused on SNR at the two highest frequencies, which are referred to hereafter as $8 \mathrm{kHz}$ and $10 \mathrm{kHz}$. The HFDPOAE parameter of SNR has been shown to have satisfactory test-retest reliability in the pediatric population, with Beahan [22] finding, in a large study of 204 normally hearing ears, no significant differences in results across separate test conditions. Furthermore, the SNR test parameter was chosen in view of its superiority over AMP for non-sound-treated screening purposes and the large standard deviations found in AMP measurements [44]. In the present study, the standard DPOAE SNR pass criterion of $\geq 6 \mathrm{~dB}$ was utilised [28].

Feedback letters were provided to caregivers immediately following testing. Participants with suspected middle ear pathology, as identified by otoscopy and/or tympanometry, and participants who failed PTA screening in one or both ears, were instructed to visit their family doctor for medical consultation and, if appropriate, referral to audiology services for further audiological investigation.

\section{Data analysis}

Data were entered into SPSS v20 software for statistical test performance analysis. Diagnostic outcomes of the HFDPOAE test were compared with those of the reference test, HFPTA. Measures of hit rate, false-alarm rate, 


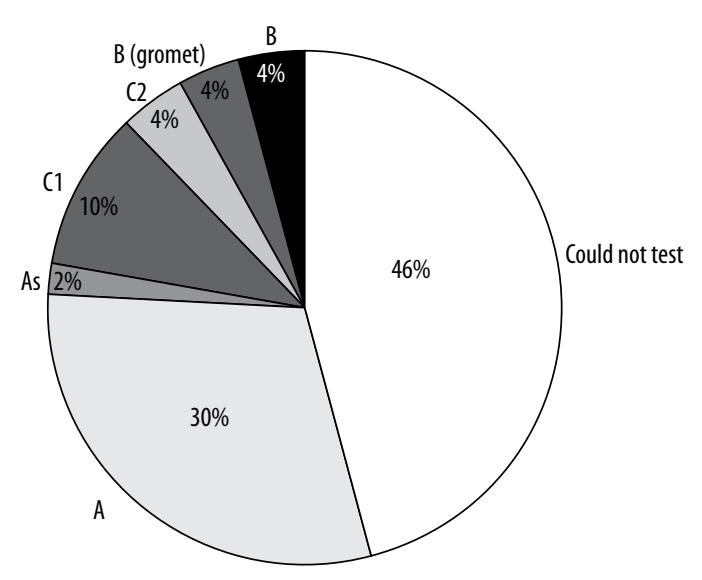

Figure 1. Tympanometry results in 50 ears of children with Down syndrome

false-negative rate, true-negative rate, posterior probabilities, efficiency index, and accuracy were calculated using clinical decision analysis. Accuracy calculations $\left(A^{\prime}\right)$ were used to indicate the probability that a randomly chosen ear with high-frequency hearing loss was correctly ranked on the HFDPOAE test with greater suspicion than a randomly chosen ear without hearing loss. A cut-off score of $\geq 0.7$ was set as an indication of adequate accuracy.

\section{Results}

In total, 50 ears (30 ears of males, 20 ears of females) of 25 children with DS were assessed. As some participants did not complete the entire test battery for either or both ears, the number of ears analysed for each test and parameter varied.

Tympanometry and pure-tone audiometry (PTA) screening

Figure 1 displays the various tympanometry results for the 50 ears. Results could not be obtained in 23 ears due to lack

Table 2. Comparison of HFDPOAE outcomes with corresponding HFPTA outcomes at $8 \mathrm{kHz}$, indicating the number of ears classified $(N=20)$

\begin{tabular}{ccc}
\hline HFDPOAE result & HFPTA pass & HFPTA fail \\
\hline SNR pass & 12 & 4 \\
\hline SNR fail & 1 & 3 \\
\hline
\end{tabular}

of subject compliance. Subsequently, 23 ears passed tympanometry and 4 ears failed with type $\mathrm{B}$ or $\mathrm{C}_{2}$ tympanograms. PTA screening results were not obtainable in 27 ears (54\%). A total of 16 ears (32\%) achieved pass results while 7 ears (14\%) failed the screening. All ears passed at $4 \mathrm{kHz}$, while 7 ears failed at $1 \mathrm{kHz}$ and 3 of these ears also failed at $2 \mathrm{kHz}$. Based on combined tympanometry and PTA screening results, 10 ears (20\%) or 5 children (20\%) were referred for medical investigation due to failing one or both of these tests.

\section{HFDPOAE and HFPTA test completion}

Completion of both key tests, HFPTA and HFDPOAE, was required for inclusion of ears in subsequent analyses. It should be noted that various techniques were used in an attempt to obtain results for both tests. Testing time was often extended to allow for difficulties in subject compliance. If feasible, testing was attempted on multiple occasions, on the same or different days. Testers provided verbal instructions along with visual demonstrations of required behavior. Play audiometry was frequently used across all age groups. Various non-verbal and verbal response modes were attempted to condition each child reliably.

For 5 ears (10\%), only HFDPOAE results could be obtained and for a further 2 ears (4\%) only HFPTA results could be obtained. For 23 ears (46\%), results were not obtained for either test for the following reasons: 19 ears were unable to be assessed due to behavioral non-compliance; 2 ears had type B tympanograms and so further testing was not pursued; and 2 ears had excessive wax. Hence, the final working database for subsequent analysis consisted of 20 ears (40\%) from 11 children who had completed both HFDPOAE and HFPTA testing ( 9 ears of males and 11 ears of females; age range $=6.3-13.7$ years; mean $=10.3$; $\mathrm{SD}=2.5$; median $=9.7$ ).

Questionnaire data were analysed for the 11 children who were included in the HFPTA and HFDPOAE comparison for at least one ear. Responses revealed caregiver concerns about the hearing abilities of 4 children (36.4\%), and a history of previous hearing tests for 8 children $(72.7 \%)$. A

Table 3. Comparison of HFDPOAE outcomes with corresponding HFPTA outcomes at $10 \mathrm{kHz}$, indicating the number of ears classified $(N=18)$

\begin{tabular}{ccc}
\hline HFDPOAE result & HFPTA pass & HFPTA fail \\
\hline SNR pass & 7 & 2 \\
\hline SNR fail & 2 & 7 \\
\hline
\end{tabular}

Table 4. Test performance measures obtained for HFDPOAE SNR against the reference standard of HFPTA (N=20 at 8 $\mathrm{kHz}, \mathrm{N}=18$ at $10 \mathrm{kHz})^{*}$

\begin{tabular}{ccccccccc}
\hline Test condition & HR & FA & FN & TN & $\operatorname{Pr}[\mathbf{D} /+]$ & $\operatorname{Pr}[\mathbf{N} /-]$ & EF & A' \\
\hline SNR $8 \mathrm{kHz}$ & 0.43 & 0.08 & 0.57 & 0.92 & 0.84 & 0.62 & 0.75 & 0.75 \\
\hline SNR $10 \mathrm{kHz}$ & 0.78 & 0.22 & 0.22 & 0.78 & 0.78 & 0.78 & 0.78 & 0.78 \\
\hline
\end{tabular}

* $\mathrm{HR}, \mathrm{FA}, \mathrm{FN}, \mathrm{TN}, \operatorname{Pr}[\mathrm{D} /+\mathrm{H}, \operatorname{Pr}[\mathrm{N} /-\mathrm{-}, \mathrm{EF}$, and A' represent hit rate, false-alarm rate, false-negative rate, true-negative rate, positive predictive value, negative predictive value, efficiency index, and accuracy, respectively 
familial history of childhood hearing loss was reported for 2 children (18.2\%), and a history of regular noise exposure was noted for 1 child (9.1\%). Responses revealed a history of ear infections or discharge for 3 children (27.3\%), and a history of ear or head surgery for 7 (63.6\%) children.

\section{HFDPOAE test performance analyses}

HFDPOAE pass/fail results for SNR were compared with HFPTA pass/fail results at 8 and $10 \mathrm{kHz}$ for each ear to evaluate the test performance of the HFDPOAE test (see Tables 2-4).

\section{Discussion}

The aim of the present study was to investigate the suitability of HFDPOAEs as a screening tool for detecting high-frequency hearing loss in children with DS. Diagnostic accuracy was determined through comparison with the HFPTA reference test. Incidental findings of the study provide insight into the general auditory status of schoolchildren with DS.

\section{Auditory status}

Tympanometry findings were encouraging, given this population's susceptibility to middle ear problems. Fail results occurred in only 4 (14.8\%) of the 27 ears tested, or 3 children $(21.4 \%)$ overall. Other studies of children with DS $[13,14]$ have reported poorer tympanometry outcomes, with fail results in approximately $30 \%$ of ears and $40 \%$ of children. In fact, failure rates in the present study were only slightly elevated from those reported in mainstream schoolchildren (13.5\% of ears, $17.9 \%$ of children) [45]. Although based on a small sample, our findings suggest an increased awareness of middle ear dysfunction in children with DS. This is reflected, perhaps, in the fact that a substantial proportion (69.2\%) of children who completed tympanometry had previously undergone ear surgery, according to returned questionnaires.

The extent of PTA failures was reasonably consistent with the lower end of generally accepted prevalence figures $(38-78 \%)$ of hearing loss in children with DS [14]. In the present study, 7 (30.4\%) of the 23 ears tested failed PTA screening, or 4 children (30\%) overall. Interestingly, all ears passed at $4 \mathrm{kHz}$. More fail results occurred at $1 \mathrm{kHz}$ (7 ears) than $2 \mathrm{kHz}$ (3 ears). Mainstream schoolchildren have similarly demonstrated poorer results at lower frequencies [45]. Issues related to the school setting, such as non-sound-treated test rooms and increased physiological noise caused by behaviors typical of schoolchildren, may be relevant. In the present study, there is the additional possibility that subtle middle ear conditions associated with DS, such as ossicular fixation [5], may have worsened thresholds at lower frequencies due to increased middle ear stiffness [46].

Behavioral issues prevented testing in a large proportion of ears for both tympanometry (46\%) and PTA screening (54\%). In particular, tympanometry was not tolerated well: completion rates were vastly poorer than the $87-100 \%$ previously reported in the literature $[13,14,47]$. This may be related to the age or degree of impairment in our small sample, as well as the increasing trend in Queensland for inclusive education, resulting in many children with less severe impairments attending mainstream schools rather than special schools.

Questionnaire responses also provided further insight into the audiologic history of our cohort of schoolchildren with DS. There were fewer caregiver concerns about hearing reported in this group (36.4\%), compared with the $70.4 \%$ of concerned caregivers reported by Driscoll et al. [13] in a similar study of schoolchildren with DS. Interestingly, upon case-by-case consideration, caregiver concern in the current study was not strongly indicative of actual hearing status. Previous hearing tests were reported for the majority of children $(72.7 \%)$. This was consistent with findings of Driscoll et al. [10] who reported previous tests in $79 \%$ of children studying in special schools. The introduction of statewide universal newborn hearing screening in 2006 may see this rate increase further. As expected, very few children indicated a familial history of childhood hearing loss or a history of regular noise exposure, whereas a substantial proportion were reported to have had ear or head surgery, and recurrent ear infections/discharge.

\section{HFDPOAE versus HFPTA}

HFDPOAE results appeared to be reasonably obtainable. A slightly larger proportion of ears were able to complete HFDPOAE (50\%) compared to HFPTA (44\%). Of the ears able to complete only one of the key tests, more ears could complete HFDPOAE than HFPTA (5 ears versus 2 ears). These findings, coupled with the shorter test time required for HFDPOAE, support clinical use of HFDPOAE in this population. Behavioral issues again impeded completion of both key tests, with 19 ears (38\%) unable to complete either test.

The reference test, HFPTA, revealed hearing within normal limits in 16 ears $(80 \%)$ at $8 \mathrm{kHz}$. Results at $10 \mathrm{kHz}$ were poorer, with only 9 ears (50\%) achieving pass results. It is unknown whether this finding is related to early-onset presbycusis [8] or to other causes. It is possible that, due to developmental delays, age-specific pass limits at $10 \mathrm{kHz}$ were not optimal. Several studies have shown children with DS and presumed normal auditory function have poorer thresholds than their typically developing counterparts. It has been reported that children with DS had conventional thresholds elevated by 9-25 dB HL $[4,48]$.

Comparison of HFDPOAE pass/fail results with those of HFPTA (Table 4) revealed an average hit rate for SNR at 8 $\mathrm{kHz}$ and a moderately high hit rate for $10 \mathrm{kHz}$. The poorer result at $8 \mathrm{kHz}$ suggests that HFDPOAE correctly detected less than $50 \%$ of hearing-impaired ears at this frequency. Complementary false-negative rates were, therefore, average and low for the respective frequencies. This raises a concern that a large proportion of hearing-impaired ears were incorrectly passed by HFDPOAE SNR at $8 \mathrm{kHz}$. However, by way of explanation, an incorrect number of ears may have been classified as hearing-impaired by the reference test. As discussed, age-specific HFPTA pass limits may have been too narrow in this population. Furthermore, the fundamentally different scope of each test must not be overlooked. HFDPOAE only assesses auditory 
function up to the cochlear outer hair cells. Increased HFPTA failures could be related to retrocochlear components of the auditory process, particularly given the atypical auditory brainstem response (ABR) patterns found in this population [15].

True-negative rates were high for both frequencies and complementary false-alarm rates were low. Hence, it appeared that HFDPOAE correctly passed most normalhearing ears, which is one of the essential features of a mass screening tool for the pediatric population.

Positive posterior probabilities were also high, indicating a good chance that a failing case will have a hearing loss. Negative posterior probabilities were moderately high. Hence, there is a less convincing chance that a pass result in HFDPOAE is a true indicator of normal hearing. Note, however, that such probability calculations are negatively influenced by the prevalence of the disorder (hearing loss) which, in this cohort and the population in gener$\mathrm{al}$, is relatively rare.

Efficiency index values were high for SNR at both frequencies. In other words, a large proportion of HFDPOAE results were correct when compared with HFPTA results.

Regarding the initial hypothesis, HFDPOAE SNR at both 8 and $10 \mathrm{kHz}$ were found to be acceptably accurate $\left(A^{\prime}>0.7\right)$ as screening parameters when compared against the reference standard of HFPTA. The generally positive test performance findings, coupled with the promising test completion rate, suggest that HFDPOAEs may be clinically appropriate for screening children with DS. HFDPOAEs may be useful as a quick verification of HFPTA results or a useful alternative for those who cannot be conditioned for HFPTA.

One major shortcoming of the project was the limited number of participants and ears able to complete both key tests. The small number of hearing-impaired ears restricted evaluation of true diagnostic accuracy. Expansion of the project to include a larger sample is recommended.

The use of HFPTA as the reference test may have also impacted test performance analyses. Although only reliable subjects were included, the behavioral issues inherent in this group may have influenced HFPTA accuracy.
Furthermore, the age-specific HFPTA pass limits used may have been too narrow, resulting in an incorrect number of ears being diagnosed as hearing-impaired. Further consideration of developmentally appropriate HFPTA normative data for this population is warranted.

Future research may benefit from considering the testretest reliability of both key tests. Poor test-retest reliability for HFPTA has been found in younger, typically developing children (4-6 years) [41]. Although our participants were generally older, developmental delays may have affected results. This issue would have presumably been less problematic for HFDPOAE testing, which has demonstrated satisfactory reproducibility at $8-10 \mathrm{kHz}$ in pediatric populations [22]. In addition, the potential issue of standing waves, worsened by the stenotic ear canals common in DS, did not appear hugely problematic in the current study given the superior test performance of $10 \mathrm{kHz}$ versus $8 \mathrm{kHz}$.

Finally, it is quite concerning that 8 children (32\%) were unable to be tested in any part of the entire test battery. The general auditory status of these subjects may easily be overlooked. Alternative measures, such as ABR under anesthesia [47], may need to be pursued in such subjects. However, due to the practical benefits of more conventional tests, further research into procedural modifications, such as those described by Kile [4], could improve completion rates in this difficult-to-test population.

\section{Conclusions}

HFDPOAE appears to offer practical benefits for screening children with DS, with HFDPOAE results more obtainable than HFPTA results. Test performance analyses suggested that SNR at 8 and $10 \mathrm{kHz}$ provided adequate accuracy for screening children with DS when compared with the reference, HFPTA. The most notable test performance finding was that HFDPOAE SNR at $8 \mathrm{kHz}$ did not appear to identify hearing-impaired ears as well as HFPTA, as evidenced by a poor hit rate. However, this is possibly related to the age-specific HFPTA pass limits being too narrow. Where feasible, complementary testing involving both HFPTA and HFDPOAE is recommended in this population. Investigations using a larger sample are required to verify these encouraging results.

\section{References:}

1. Balkany TJ, Downs MP, Jafek BW et al. Hearing loss in Down's syndrome: A treatable handicap more common than generally recognized. Clin Pediatr 1979; 18: 116-8.

2. Shott SR. Down syndrome: common otolaryngolic manifestations. Am J Med Genet C Semin Med Genet 2006;142C: 131-40.

3. Park AH, Wilson MA, Stevens PT et al. Identification of hearing loss in pediatric patients with Down syndrome. Otolaryngol Head Neck Surg, 2012; 146: 135-40.

4. Kile JE. Audiologic assessment of children with Down syndrome. Am J Audiol, 1996; 5: 44-52.

5. Kanamori G, Witter M, Brown J et al. Otolaryngolic manifestations of Down syndrome. Otolaryngol Clin North Am, 2000; 33: 1285-92.
6. Dille MF. Perspectives on the audiological evaluation of individuals with Down syndrome. Semin Hear, 2003; 24: 201-10.

7. Ramia M, Musharrafieh U, Khaddage W et al. Revisiting Down syndrome from the ENT perspective: review of the literature and recommendations. Eur Arch Otorhinolaryngol 2013; May.

8. Buchanan LH. Early onset of presbyacusis in Down syndrome. Scand Audiol, 1990; 19: 103-10.

9. Rappaport JM, Provencal C. Neuro-otology for audiologists. In: Katz J, editor. Handbook of Clinical Audiology. $5^{\text {th }}$ ed. Baltimore: Lippincott Williams \& Wilkins; 2002; 9-32.

10. Driscoll C, Kei J, Bates D et al. Transient evoked otoacoustic emissions in children studying in special schools. Int J Pediatr Otorhinolaryngol, 2002; 64: 51-60. 
11. Kumar Sinha A, Montgomery JK, Herer GR et al. Hearing screening outcomes for persons with intellectual disability: a preliminary report of findings from the 2005 Special Olympics World Winter Games. Int J Audiol, 2008; 47: 399-403.

12. Bennetts LK, Flynn MC. Improving the classroom listening skills of children with Down syndrome by using sound-field amplification. Downs Syndr Res Pract, 2002; 8: 19-24.

13. Driscoll C, Kei J, McPherson B. Tympanometry and TEOAE testing of children with Down syndrome in special schools. Aust N Z J Audiol, 2003; 25: 85-93.

14. McPherson B, Lai SP, Leung KK et al. Hearing loss in Chinese school children with Down syndrome. Int J Pediatr Otorhinolaryngol, 2007; 71: 1905-15.

15. Kaga K, Marsh RR. Auditory brainstem responses in young children with Down's syndrome. Int J Pediatr Otorhinolaryngol, 1986; 11: 29-38.

16. Roizen NJ, Wolters C, Nicol T et al. Hearing loss in children with Down syndrome. J Pediatr, 1993;123: 9-12.

17. Koike KJ, Wetmore SJ. Interactive effects of the middle ear pathology and the associated hearing loss on transient-evoked otoacoustic emission measures. Otolaryngol Head Neck Surg, 1999; 121: 238-44.

18. Best V, Carlile $\mathrm{S}$, Jin $\mathrm{C}$ et al. The role of high frequencies in speech localization. J Acoust Soc Am, 2005; 118: 353-63.

19. Dreisbach LE, Siegel JH. Distortion-product otoacoustic emissions measured at high frequencies in humans. J Acoust Soc Am, 2001; 110: 2456-69.

20. Harris FP. Distortion-product otoacoustic emissions in humans with high frequency sensorineural hearing loss. J Speech Hear Res, 1990; 33: 594-600.

21. Beahan N, Reichman E, Kei J et al. DPOAE changes in young children with confirmed hearing loss due to ototoxicity. Aust N Z J Audiol, 2006; 28: 90-105.

22. Beahan $\mathrm{N}$. Investigating high frequency auditory function in normally hearing children and children receiving anti-cancer chemotherapy. Doctoral dissertation. Brisbane, Australia: University of Queensland; 2010.

23. Dreisbach LE, Long KM, Lees SE. Repeatability of high-frequency distortion-product otoacoustic emissions in normalhearing adults. Ear Hear, 2006; 27: 466-79.

24. Lyons A, Kei J, Driscoll C. Distortion product otoacoustic emissions in children at school entry: a comparison with pure-tone screening and tympanometry results. J Am Acad Audiol, 2004; 15: 702-15.

25. Gorga MP, Neely ST, Dorn PA. Distortion product otoacoustic emission test performance for a priori criteria and for multifrequency audiometric standards. Ear Hear, 1999; 20: 345.

26. Beahan N, Kei J, Driscoll C et al. High frequency pure tone audiometry $(8-16 \mathrm{kHz})$ in children: a normative study. Aust N Z J Audiol, 2009; 31: 33-44.

27. Siegel JH, Hirohata ET. Sound calibration and distortion product otoacoustic emissions at high frequencies. Hear Res, 1994; 80: $146-52$.

28. Zebian M, Hensel J, Fedtke $\mathrm{T}$ et al. Interpretation of distortion product otoacoustic emissions at higher frequencies. J Hear Sci, 2011; 1: 49-51.

29. Hecker DJ, Lohscheller J, Bader C et al. A new method to analyze distortion product otoacoustic emissions (DPOAEs) in the high-frequency range up to $18 \mathrm{kHz}$ using windowed periodograms. IEEE Trans Biomed Eng, 2011; 58: 2369-77.
30. Topolska MM, Hassman E, Baczek M. The effects of chronic otitis media with effusion on the measurement of distortion products of otoacoustic emissions: presurgical and postsurgical examination. Clin Otolaryngol Allied Sci, 2000; 25: 315-20.

31. Kei J, Brazel B, Crebbin K et al. High frequency distortion product otoacoustic emissions in children with and without middle ear dysfunction. Int J Pediatr Otorhinolaryngol, 2007; 71: 125-33.

32. Tas A, Yagiz R, Uzun C et al. Effect of middle ear effusion on distortion product otoacoustic emission. Int J Pediatr Otorhinolaryngol, 2004; 68: 437-40.

33. Flynn MC, Bennetts LK. Improving the classroom listening skills of children with Down syndrome by using sound-field amplification. Downs Syndr Res Pract, 2002; 8: 19-24.

34. McDermott AL, Williams J, Kuo MJ et al. The role of bone anchored hearing aids in children with Down syndrome. Int $\mathrm{J}$ Pediatr Otorhinolaryngol, 2008; 72: 751-7.

35. Jerger JF. Clinical experience with impedance audiometry. Arch Otolaryngol, 1970; 92: 311-24.

36. Australian Standards AS IEC 60645.1-2002. Pure Tone Audiometers. Sydney: Standards Association of Australia; 2002.

37. Australian Standard AS ISO 389.1-2007. Acoustics - Reference zero for the calibration of audiometric equipment - Reference equivalent threshold sound pressure levels for pure tones and supra-aural earphones in the range 0.125 to $8 \mathrm{kHz}$. Sydney: Standards Association of Australia; 2007.

38. Australian Standards AS ISO 389.5-2003. Acoustics - Reference zero for the calibration of audiometric equipment. Part 5: Reference equivalent threshold sound pressure levels for pure tones in the frequency range 8 to $16 \mathrm{kHz}$. Sydney: Standards Association of Australia; 2003.

39. Stelmachowicz PG, Beauchaine KA, Kalberer A et al. High frequency audiometry: test reliability and procedural considerations. J Acoust Soc Am, 1989; 85: 879-87.

40. Carhart R, Jerger JF. Preferred method for clinical determination of pure-tone thresholds. J Speech Hear Disord, 1959; 24: 330-45.

41. Beahan N, Kei J, Driscoll C et al. High-frequency pure-tone audiometry in children: a test-retest reliability study relative to ototoxic criteria. Ear Hear, 2012; 33: 104-11.

42. Whitehead ML, Stagner BB, Lonsbury-Martin BL et al. Effects of ear-canal standing waves on measurements of distortion-product otoacoustic emissions. J Acoust Soc Am, 1995; 98: 3200-14.

43. Stover L, Gorga MP, Neely ST et al. Toward optimizing the clinical utility of distortion product otoacoustic emission measurements. J Acoust Soc Am, 1996; 100: 956-67.

44. O’Rourke C, Driscoll C, Kei J et al. A normative study of otoacoustic emissions in 6-year-old schoolchildren. Int J Audiol, 2002; 41: 162-9.

45. Driscoll C, Kei J, McPherson B. Outcomes of transient evoked otoacoustic emission testing in 6-year-old school children: a comparison with pure tone screening and tympanometry. Int J Pediatr Otorhinolaryngol, 2001; 57: 67-76.

46. Stach BA. Clinical Audiology: An introduction. Clifton Park, NY: Delmar Cengage Learning; 2010.

47. Hassman E, Skotnicka B, Midro AT et al. Distortion products otoacoustic emissions in diagnosis of hearing loss in Down syndrome. Int J Pediatr Otorhinolaryngol, 1998; 45: 199-206.

48. Werner LA, Mancl LR, Folsom RC. Preliminary observations on the development of auditory sensitivity in infants with Down syndrome. Ear Hear, 1996; 17: 455-68. 